\title{
Goats And The Need For Range Management In Mexico
}

\section{Current goat production practices in the state of Durango, Mexico have lead to overgrazing and a need for educating producers about range management. Here's a history.}

\author{
By Edmundo Castellanos-Perez, Manuel Valencia-Castro, Jesus J. Quiñones-Vera
}

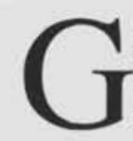
oat production in the Chihuahuan Desert in Mexico is carried out by the poorest livestock producers of the country. Goats provide milk which is a source of a daily income or at least provides producers with an inexpensive source of protein. The reproduction of goats is also a means to increase the producer's income in one season of the year and in rare occasions the reproduction of goat kids happens two seasons of the year.

Following is an overview of the main goat production systems in the region of the Durango State corresponding to the Chihuahuan Desert. In this area, there are two dominant systems, the extensive system in rangelands dominated by brushwood vegetation in Ejidos, and another extensive system where goats graze crop residuals, grasses growing in water channels, and weeds in the intensive agriculture area in the region named La Comarca Lagunera.

\section{Goats On Brushwood Rangelands}

The information in this system is based on an overview of the Ejido Pasaje that belongs to Cuencame County of the State of Durango. This Ejido is located at $24^{\circ} 54^{\prime}$ north latitude and $103^{\circ} 47^{\prime}$ western longitude. Vegetation is crassicauleous brushwood dominated by species of Opuntia, Acacia, Agave, Eysenhardtia, Rhus, Prosopis, Celtis, Lycium and others. Also some areas are dominated by Larrea tridentata and Fluorensia cernua. Precipitation average is $300 \mathrm{~mm}$ occurring mainly in the summer, average temperature of the coldest month is $10-20^{\circ} \mathrm{C}$ and the hottest $20-30^{\circ} \mathrm{C}$ (Medellin-Leal 1982). The total area is $28,000 \mathrm{ha}$, where there are 412 ejidatarios, the owners of this land, and 112 of them have goats.

Each ejidatario has 5 to 20 ha dedicated to the agriculture of private propriety. This land is provided for by a new law

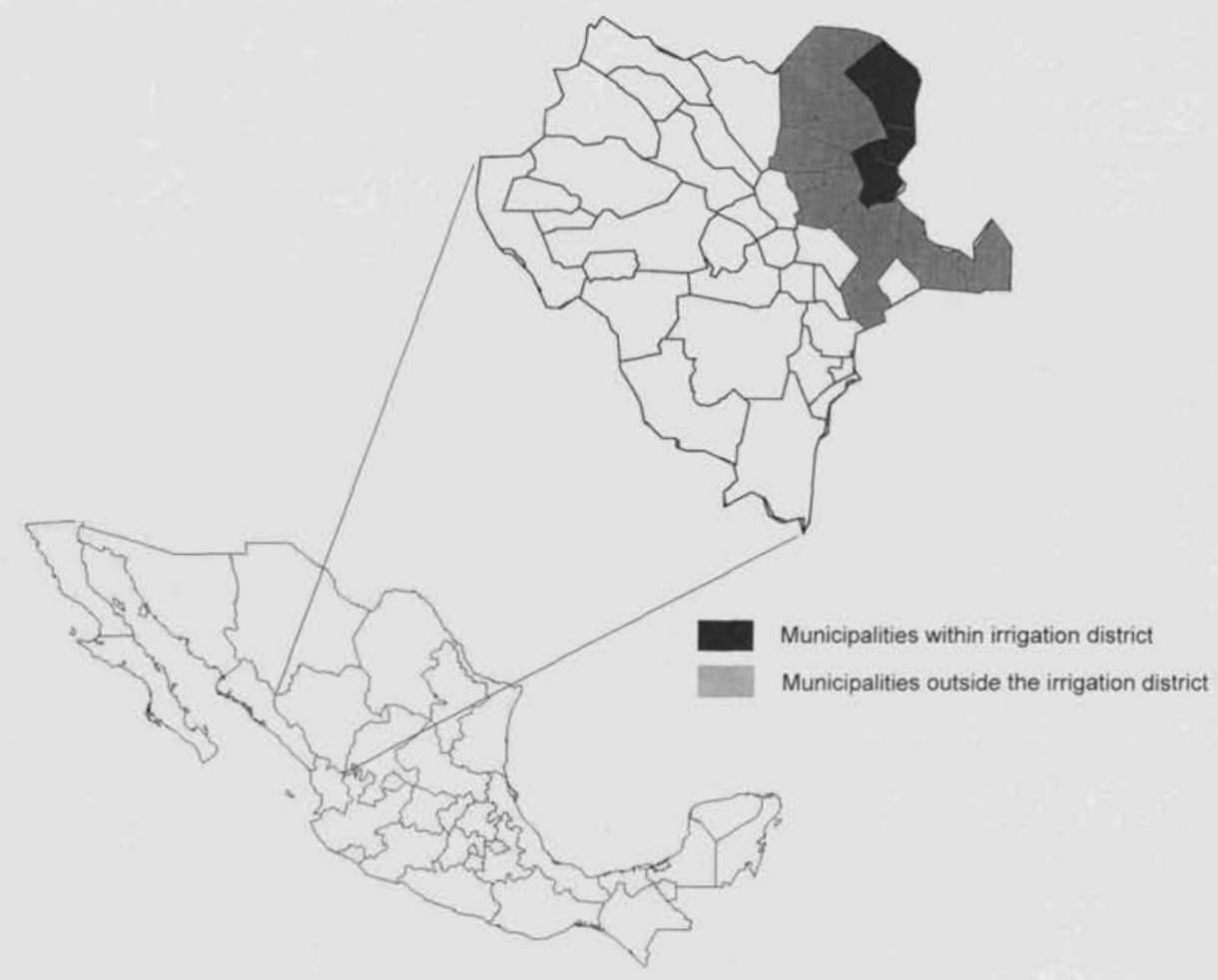


written in the government of the ex-president of Mexico Salinas-de Gortari (1988-1994). The areas of agriculture are mainly irrigated with runoff water diverted from arroyos. This type of farming means that ejidatarios have crop production only after summer rainfall occurs. The area not dedicated to agriculture is mainly dominated by brushwood vegetation, grazed by livestock and some deer. This area is for common use, in other words, all the ejidatarios can use this area if they have animals to collect the forage. Generally, each ejidatario has private cattle and/or goats, and they use burros, mules, and/or horses for transportation.

Goat grazing in this extensive system is basically opportunistic. Goats are moved to any area where rainfall has occurred and the vegetation has become green. To maintain water in these areas of green vegetation, people make jaguieyes, which are small dams of soil across the arroyos bottoms. This traps the runoff water. Ejidatarios know that if there is no winter rainfall the forage production of the brush vegetation will be minimum with the period from January to June having a critical food shortage. During this period, water is provided from dug wells or natural springs. These areas near the water have a high degree of overgrazing (Holechek et al. 1995).

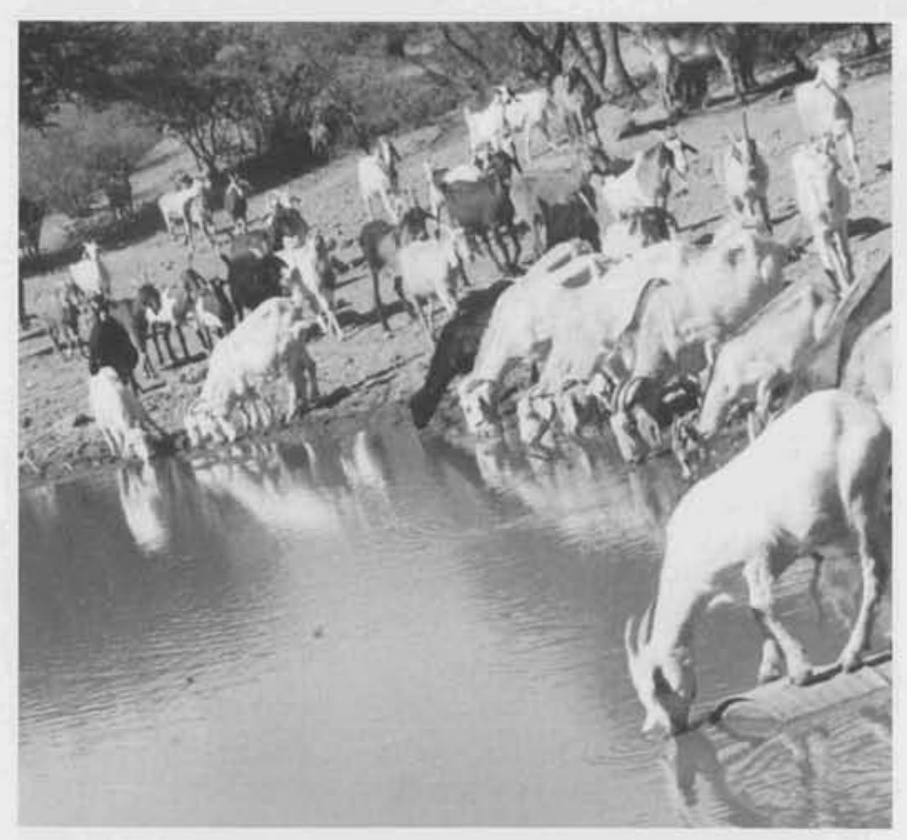

A jagüey with goats drinking water.

Corrals are very rustic because herds are moved three times per year, always searching for the best grazing area or the availability of water in the winter through spring period. Corrals are made using stems and branches of mesquite, white-thorn (Acacia constricta), ocotillo (Fouquieria splendens), and other shrubs.

In this area, producers invest a great deal of energy taking care of their animals, but they pay little attention to im- proving the grazing range. They always try to move their animals to the best forage areas, to make sure that goats get the best food available. The worst thing for a livestock producer is to see animals die due to starvation during drought periods usually between July and September.

Emergency forage is provided by burning the spines of Opuntia imbricata. Another plant used is the palma (Yucca spp) which is cut, then the sharp blades are taken away and the stem is cut in small pieces $(2 \times 2 \times 2 \mathrm{~cm}$ approximately). They also collect nopal (Opuntia spp) and after burning the sharp needles, the 'pencas' (racquets) are cut in small pieces and given to the goats.

Since each ejidatario owns as many animals as he can feed and they all use the common rangeland areas of the ejido without any restrictions, everyone tries to get the plant products, (in this case: the forage) without considering the remaining part of the plant and its implications for the next growing season. Unfortunately, that practice leads to overgrazing (Committee on Rangeland Classification 1994). Additionally, severe droughts contribute to a serious problem of soil erosion which often results in big gullies (Ellis and Swift 1988, Gibbens and Beck 1988).

Ejidatarios do see the problem but they assume that if they do not use the grasses or shrub forage of the ejido, other ejidatarios will do it. This overgrazing is a common problem in the rangelands that support the goat or beef cattle industry.

Erosion is notorious in bajadas (alluvial plains with a light slope), where large bare ground patches are visible. Runoff erosion has accelerated the formation of huge deep gullies. Local people say that in areas where they built jaguieyes in the past they had a good grass ground cover. Unfortunately, overgrazing plus droughts have turned many of these grassland areas into less than favorable grazing locations.

It is important to understand the animal reproduction procedure in these areas. In the late nineteenth century, before that area became an ejido, there was a restrictive use and reproduction program that followed the summer rainfall period. At that time, they separated the male goats from April to January, joining male and female goats in February, usually one male for 25-30 females in each herd. That practice allowed the production of kids in June and July just in time for the summer rainfall. During the years that rainfall amounts were over the average, they would join the males and female goats at the end of the summer. That practice provided an additional income in the winter from the sale of the kids.

Since the average herd is between 100 to 300 animals, they have a uniform nursery method. When a female goat has parturition, the kid or kids are tagged with a number by cutting hair on the left side of the rumen. Also the same number is tagged to its mother on the same place. Female goats graze without their kids. The kids are left in the corral because they are too young to walk the several kilometers per day that the goats usually have to cover to get their 


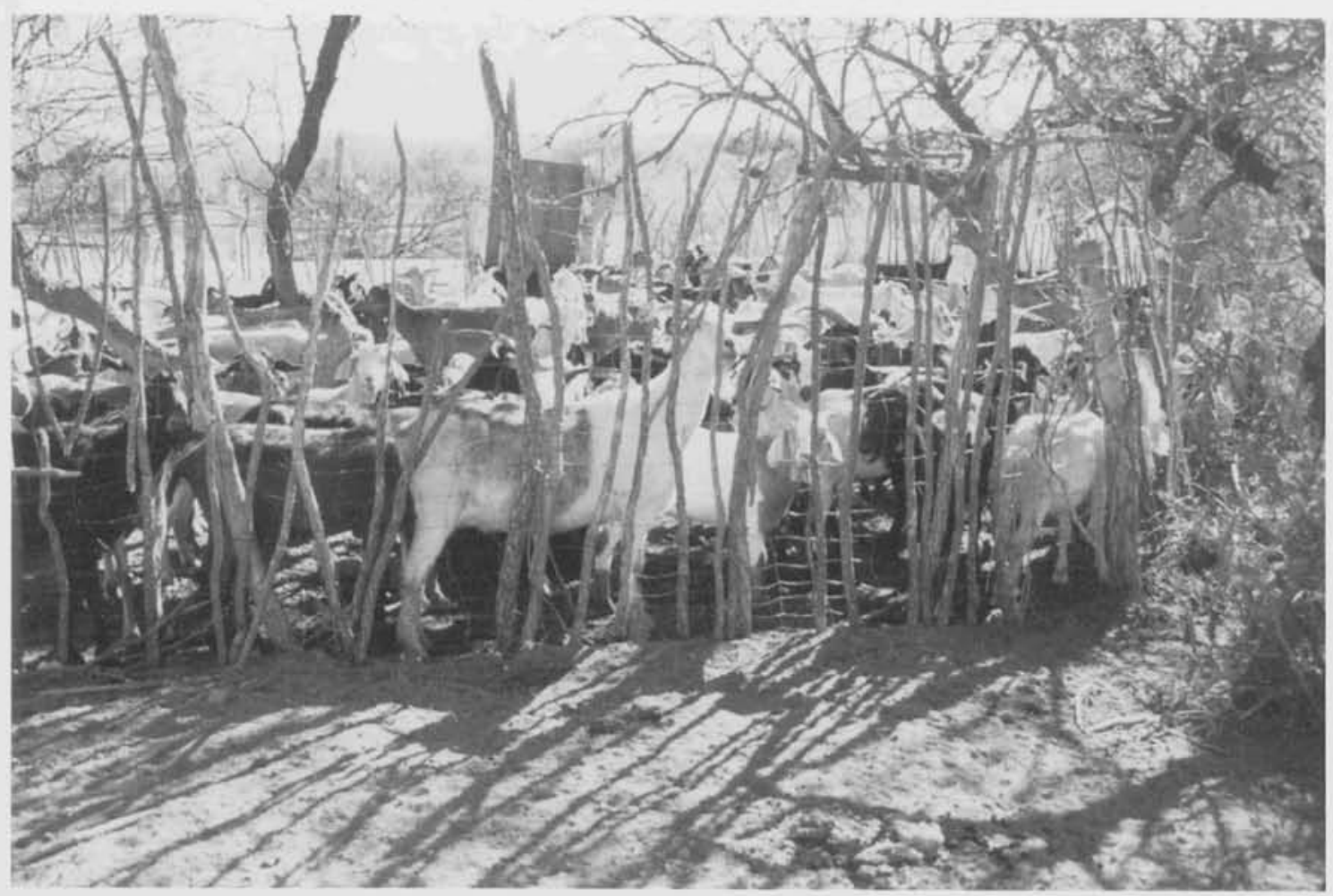

A corral made with ocotillo stems.

forage in the rangelands. Before goats come back to the corral, around sunset, a worker ties the kids in their respective place by putting one end of a thin rope around one leg and the other side of the rope is tied to a wood stake buried in the ground. In this way female goats always know where they can locate their kids to nurse them.

When female goats are close to the parturition time they are left in the corral one or two days until after birth occurs. When a mistake is made and a female goat is not left in the corral during that time and its kids are borne at the grazing area, the kids are nourished and tied by their four legs around the neck of their mother until they arrive to the corral in the evening.

The percentage of twin births is around 50\% and generally the young goats start breeding from the time they turn 18 months old. Adult goats are sold when they are 6-7 years old depending on their reproductive record or the needs of the livestock producer. The milk production period is $3-5$ months after parturition. Ejidatarios in this region do not use any kind of vaccines in their animals and supplemental protein and mineral use is rare in this kind of system.

\section{Goat Production In Intensive Ag Areas}

The Comarca Lagunera is an intensive agricultural area by using mainly water of the Nazas river that originates in the Sierra Madre Occidental. Another important river is the Aguanaval river which begins in the Zacatecas State. Both rivers used to flow to a closed watershed in the lagoon named Laguna de Mayran, but the dams and channels built for a better irrigation control has dried this lagoon. The Comarca Lagunera is located between $24^{\circ} 30^{\prime}$ and $27^{\circ}$ north latitude and between $102^{\circ}$ and $104^{\circ} 40^{\prime}$ west longitude. The average rainfall in this area is $200 \mathrm{~mm}$, precipitation occurs mainly in the summer season and winter is usually dry. The average temperature in the coldest month is between 10 and $20^{\circ} \mathrm{C}$ and the hottest month is $20-30^{\circ} \mathrm{C}$ (Medellin-Leal 1982).

Forages are obtained mainly for dairy cattle, and there are some areas with irrigated crops producing corn, bean, and cotton. Usually people who live and raise goats in this rural area generally do not have any private or ejidal possession of land. They use goats for collecting residuals of crops where there are not fences. Goats also graze former croplands that have been abandoned due to the decrease of the water availability. Fourwing saltbush (Atriplex canescens) and mesquite have invaded these areas. The evergreen fourwing saltbushes are good forage for the goats.

In these areas, the highest availability of forage is in the summer and fall seasons because the rainfall is used by plants growing in abandoned areas and moreover in the fall season there is crop residual in areas where bean or maize were harvested. Low amounts of forage from January to June is observed because there are no residuals of crops of the winter season.

The reproduction of goats according to Valencia-Castro (1998) is determined by producers who breed their females usually once per year, where $37 \%$ of the livestock operators maintain the males with the female goats the whole year, 
and a $34 \%$ breed their goats from June to September. Usually kid production is from November to September. Producers only have a rustic corral for protection in the night. They rarely give supplementation to their goats. Daily milk is produced for $3-5$ months long after the parturition. People take care about animal health because they see low production or weight loss when animals get sick. Mortality is about $9 \%$ in adult animals and abortion about $12 \%$ due to low nutrition levels or illness. In this area there is not a problem of overgrazing.

\section{A Need For Range Management}

Whereas there is severe overgrazing in the area of brushwood rangelands, this is not a real problem in the agriculture areas. In the brushwood rangelands, people are aware that their goats are overgrazing the land because a lack of internal control in the Ejido. It is necessary to organize and create a grazing system where the priority will be at least to stop overgrazing. Although this action alone will not return rangelands to their initial condition, at least, it will be the beginning of actions conducive to the restorations of these areas.

The life of the goat producer is hard, and he lives in poor conditions. Grazing on these eroded lands is difficult to get access to good forage and water each day. The producer knows it, therefore if these people had access to other options they would leave this activity or they would accept an adequate management system of the renewable resources of these lands. If they could be confident that the distribution of land use would be fair they would forget their present motto "if my animals do not eat these plants, other animals that are not mine will eat them anyway and I will not get any benefits".

They need to know how to take care of their rangelands and they need to understand some of the ecological processes that plants endure (Joyce et al. 1999). With the help from rangeland managers, they would know when plants must be grazed and how much biomass would be removed without any damage to the plants and the environment (Holechek et al. 1995). Furthermore, it is very important to establish a law which mandates a change in the overgrazing pattern that has created a dangerous situation in the rangeland of Mexico and is very detrimental to our nation.

Authors are associated professors at Facultad de Agricultura y Zootecnia, Universidad Juarez del Estado de Durango, Mexico.

\section{References}

Committee on Rangeland Classification. 1994. Rangeland Health: New Methods to Classify, Inventory, and Monitor Rangelands. Board on Agriculture, National Research Council. Washington DC. 180 p.

Ellis, J.E. and D.M. Swift. 1988. Stability of African pastoral ecosystems: Alternate paradigms and implications for development. J. Range Manage. 41:450-459.

Gibbens , R.P. and R.F. Beck. 1988. Changes in grass basal area and forb densities over a 64-year period on grassland types of the Jornada Experimental Range. J. Range Manage. 41:186-192

Holechek, J.L., R.D. Pieper, and C.H. Herbel. 1995. Range Management: Principles and Practices. $2^{\text {nd }}$ ed.Prentice-Hall. Englewood Cliffs, NJ.

Joyce, L.A., J.J. Landsberg, M. Stafford Smith, J. Ben-Asher, J.R. Cavazos Doria, K. Lajtha, G.E. Likens, A. Perevolotsky, and U.N. Safriel. 1999. Ecosystem-level consequences of management options, p. 97-113. In: T.W. Hoekstra and M. Shachak (eds). Arid Lands Management:Toward Ecological Sustainability. University of Illinois Press. Urbana and Chicago, III.

Medellin-Leal, F. 1982. The Chihuahuan desert, p. 321-381. In: G.L. Bender (ed). Reference Handbook on the Deserts of North America. Greenwood Press. Wesport, Connecticut.

Valencia-Castro M. 1998. Sistemas de produccion caprina en la Comarca Lagunera. Memorias del ler. Congreso Internacional de Medicos Veterinarios Zootecnistas Practicantes en Rumiantesde La Comarca Lagunera. Gomez Palacio, Dgo. 22 y 23 de Mayo de 1998. pp 191-201

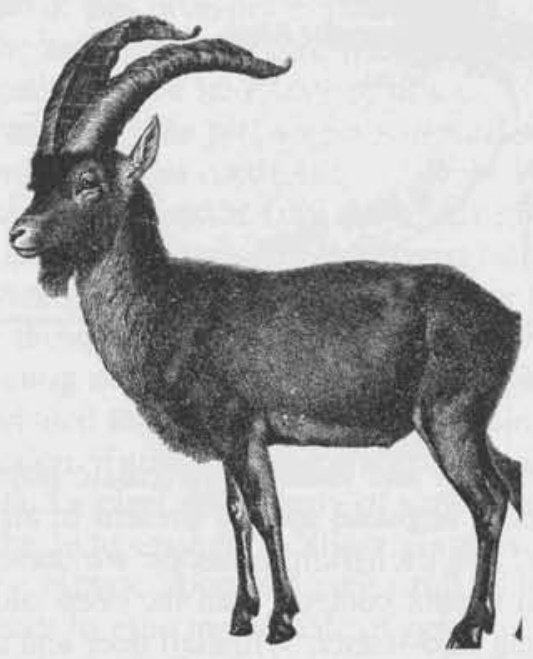

